\title{
CHARACTERIZATION OF TEXTILE INDUSTRIES' EFFLUENTS IN KADUNA, NIGERIA AND POLLUTION IMPLICATIONS
}

\author{
R.O. YUSUFF ${ }^{1}$ \\ J.A. SONIBARE ${ }^{2, *}$
}

\author{
${ }^{1}$ Department of Chemical Engineering \\ Ladoke Akintola University \\ Ogbomoso. Nigeria \\ ${ }^{2}$ Environmental Engineering Research Laboratory \\ Department of Chemical Engineering \\ Obafemi Awolowo University \\ Ile-Ife, Nigeria
}

Received: 2/6/2004

*to whom all correspondence should be addressed:

Tel.: + 234-08033837896

Accepted: 9/2/2005

e-mail: asonibar@oauife.edu.ng

\begin{abstract}
Effluents from five major textile industries in Kaduna (Nigeria) were characterized for a proposed central effluent treatment plant. Seven of the measured parameters exceeded the limit set by the Federal Ministry of Environment. Colour intensity exceeded it in all the samples (Mills $1-5$ ) by about 350 folds on the average while COD, TSS, $\mathrm{NH}_{3}, \mathrm{BOD}_{5}$, and $\mathrm{S}^{2-}$ were by $24,13,8,7$ and 3 folds respectively. TDS was detected in all samples with limit exceeded only in Mill 2. Nitrate, oil and grease were detected in Mills 1 and 2 and within the limit. Al, Mn, and Zn were detected in $80 \%$ and within the limit while Fe was detected in $60 \%$. Cu was detected in $80 \%$ with limit exceeded about 3 folds on the average. The present study is focused on the pollution implications of these effluents from textile operations in the city; important because of the risk of human exposure to them.
\end{abstract}

KEYWORDS: Textile mill, effluent, pollution, Kaduna, mitigation.

\section{INTRODUCTION}

Industrial pollution is one of the problems presently facing Nigeria and several efforts are being vigorously pursued to control it in various industries spanning length and breadth of the country to see that Nigerians live in a diseasefree environment. Effluent generated by the industries is one of the sources of pollution. Contaminated air, soil, and water by effluents from the industries are associated with heavy disease burden (WHO, 2002) and this could be part of the reasons for the current shorter life expectancy in the country (WHO, 2003) when compared to the developed nations. Some heavy metals contained in these effluents (either in free form in the effluents or adsorbed in the suspended solids) from the industries have been found to be carcinogenic (Tamburlini et al., 2002) while other chemicals equally present are poisonous depending on the dose and exposure duration (Kupchella and Hyland, 1989). These chemicals are not only poisonous to humans but also found toxic to aquatic life (WHO, 2002) and they may result in food contamination (Novick, 1999).

Ammonia is harmful to fish or other aquatic organisms at free (un-ionized) concentration of $10-50 \mu \mathrm{g} / \mathrm{l}$ or higher $\mathrm{pH}$ and the sulphide in the 
effluent are of environmental concern (WHO, 2000) because they can lead to poor air quality of an area if not properly taken care of thus becoming threat to human, vegetation, and materials. The same is applicable to $\mathrm{pH}$ that has been identified to raise health issue if water available for human use is not of the required level (WHO, 1993). Textile industries are major sources of these effluents (Ghoreishi and Haghighi, 2003) due to the nature of their operations which requires high volume of water that eventually results in high wastewater generation. They are one of the largest of water users and polluters (Nemerow, 1978)

Kaduna (Lat. $10.52{ }^{\circ} \mathrm{N}$, Long $7.44^{\circ} \mathrm{E}$ ) located in Kaduna State occupies central portion of Northern Nigeria (Kaduna, 2004). Founded in 1917 as an administrative headquarters of Northern Nigeria, it is presently one of the most important cities in the country. As at 1991 (the last official census date in Nigeria) it had a population of 993,600 but currently projected to be home to about 1,563,300 (TWG, 2004) people. Apart from presently being the administrative headquarters of its state it has a high concentration of Federal Parastatals, Schools, and other public institutions.
Industrially, it is one of the most developed cities in Northern Nigeria and textile industries are some of its dominating industries. It is on record that the first textile industry in Nigeria was established in this city (Jibrin, 2004) and this could be one of the reasons for its high population density (Olanrewaju, 2001), a reason for the importance of this study.

River Kaduna, a major river in the city receives the effluents from these industries. It does not only run across the entire city but also, it is a major tributary of the Niger River (Gefu and Kolawole, 2002), an indication of the extent to which pollutants in the effluent can reach (Figure 1). As a Northern Nigerian city, Kaduna is characterized with high evaporation during the long dry season. This could result in volatilization of chemicals in the effluents and release of heavy metals as particulates due to their adsorption on the effluents' solids. Thus, air quality around the banks of this River and the entire city could be negatively affected. This calls for a proper treatment of effluents from the industries to be sure that environmental indicators do not exceed the set limit at any point in time.

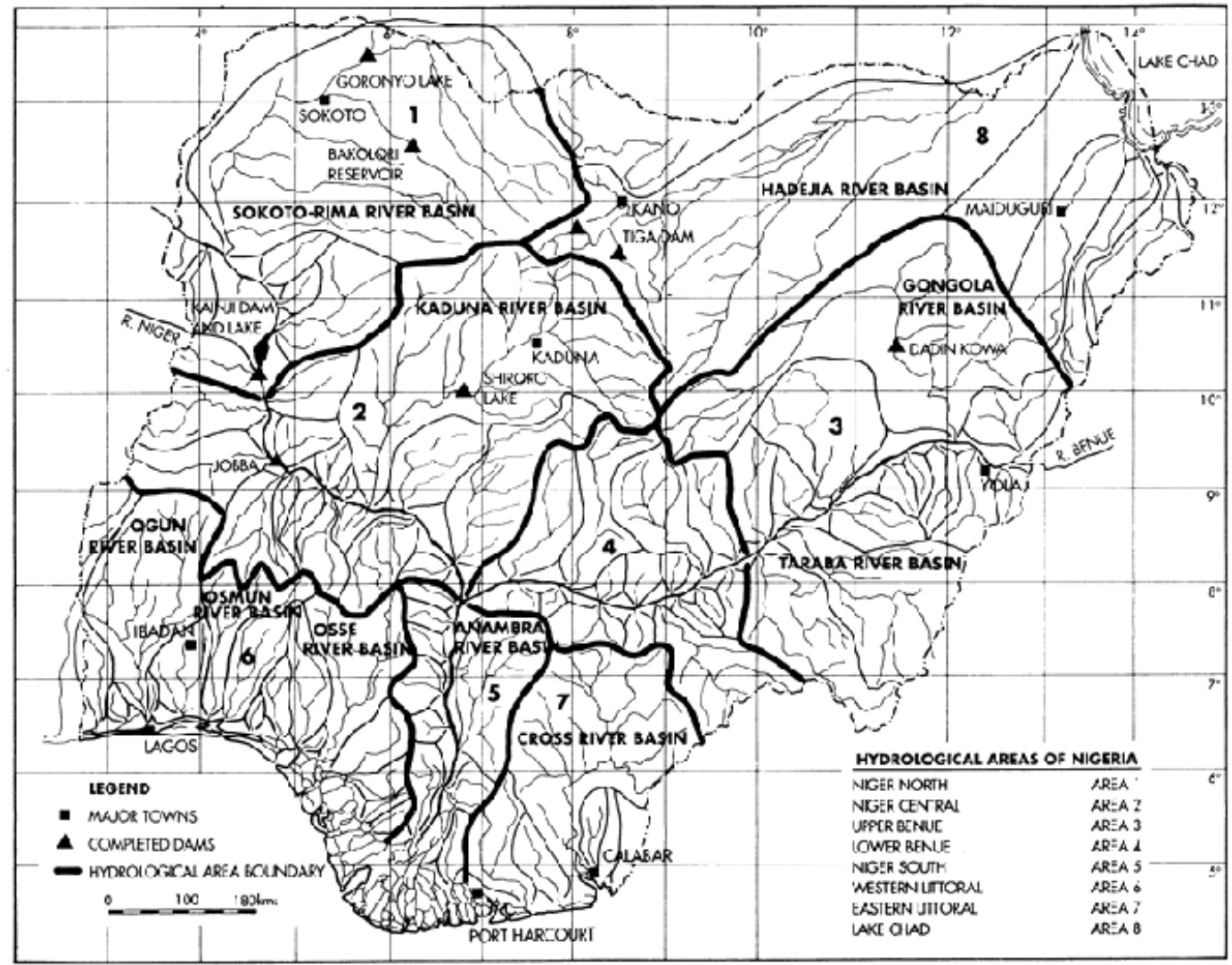

Figure 1. Hydrological Map of Nigeria Indicating Kaduna River Basin (Ita, 1994) 
The textile industry is distinguished by raw material used and this determines the volume of water required for production as well as wastewater generated. Production may be from raw cotton, raw wool, and synthetic materials but in Kaduna city, the five major industries studied are raw cotton-based. In this type of production, slashing, bleaching, mercerizing, and dyeing are the major consumption activities as well as wastewater generation (Figure 2). The nature of the processing exerts a strong influence on the potential impacts associated with textile manufacturing operations due to the different characteristics associated with these effluents (Table 1). Specific water use varies from 60-400 $\mathrm{l} / \mathrm{kg}$ of fabric, depending on the type of fabric (PRG, 1998; AEPA, 1998). Every process and operation within a textile dyeing and finishing plant has an environmental aspect that should be considered and for which environmental performance can potentially be improved. This is in addition to the input of a wide rage of chemicals, which, if not contained in the final product, become waste treatment and disposal problems.

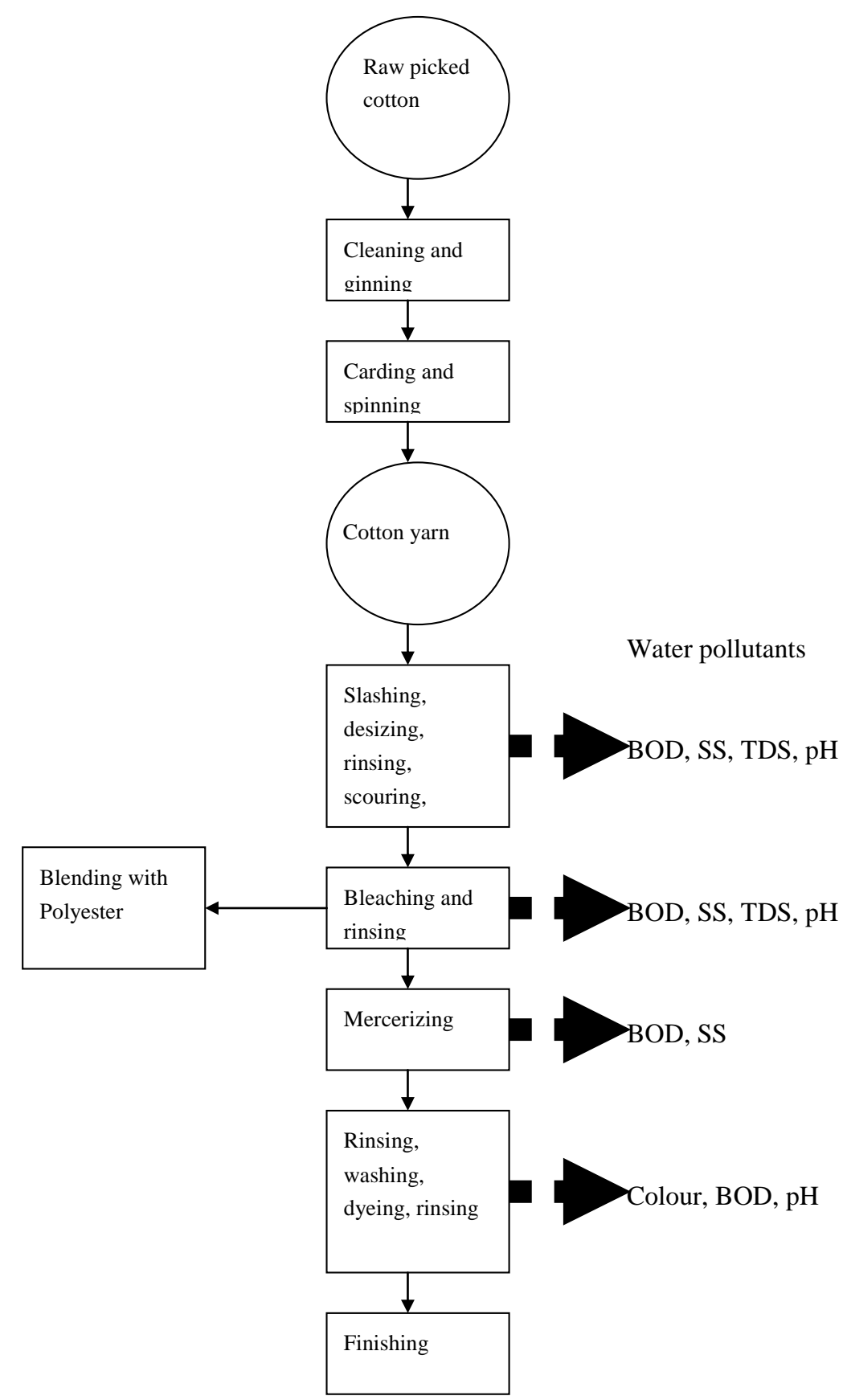

Figure 2. Cotton Fabric Production and Associated Water Pollutants 
Table 1. Effluent Characteristics From Textile Industry

\begin{tabular}{|c|c|c|}
\hline Process & Effluent composition & Nature \\
\hline Sizing & $\begin{array}{l}\text { Starch, waxes, carboxymethyl cellulose (CMC), } \\
\text { polyvinyl alcohol (PVA), wetting agents. }\end{array}$ & High in BOD, COD \\
\hline Desizing & Starch, CMC, PVA, fats, waxes, pectins & $\begin{array}{l}\text { High in BOD, COD, SS, dissolved } \\
\text { solids (DS) }\end{array}$ \\
\hline Bleaching & $\begin{array}{l}\text { Sodium hypochlorite, } \mathrm{Cl}_{2}, \mathrm{NaOH}, \mathrm{H}_{2} \mathrm{O}_{2} \text {, acids, } \\
\text { surfactants, } \mathrm{NaSiO}_{3} \text {, sodium phosphate, short } \\
\text { cotton fibre. }\end{array}$ & High alkalinity, high SS \\
\hline Mercerizing & Sodium hydroxide, cotton wax & High pH, low BOD, high DS \\
\hline Dyeing & $\begin{array}{l}\text { Dyestuffs urea, reducing agents, oxidizing agents, } \\
\text { acetic acid, detergents, wetting agents. }\end{array}$ & $\begin{array}{l}\text { Strongly coloured, high BOD, DS, } \\
\text { low SS, heavy metals }\end{array}$ \\
\hline Printing & $\begin{array}{l}\text { Pastes, urea, starches, gums, oils, binders, acids, } \\
\text { thickeners, cross-linkers, reducing agents, alkali. }\end{array}$ & $\begin{array}{l}\text { Highly coloured, high BOD, oily } \\
\text { appearance, SS slightly alkaline, low } \\
\text { BOD }\end{array}$ \\
\hline
\end{tabular}

Source: PRG, 1998.

Key environmental issues associated with textile manufacture are water use, treatment and disposal of aqueous effluent. The risk factors are primarily associated with the wet processes scouring, desizing, mercerizing, bleaching, dyeing and finishing. Desizing, scouring and bleaching processes produce large quantities of wastewater. Treatment for colour removal can increase the risk pollution. For instance, treating azo-dyes results in production of amines which could be a greater environmental risk than the dye itself.

Villegas - Navarro et al. (2001) reported that textile effluents are foxier in terms of $\mathrm{LC}_{50}$ and exhibit very high toxicity with acute toxicity unit (ATU) levels between 22 and 960. Dyes contributed to overall toxicity at all process stages. Also, dye baths could have high level of BOD/COD, colour, toxicity, surfactants, fibres and turbidity, and may contain heavy metals (AEPA, 1998). They generally constitute a small fraction of total liquid effluent, but may contribute a high proportion of total contaminants. Wynne et al. (2001) noted that textile effluents are highly coloured and saline, contain non-biodegradable compounds, and are high in Biochemical and Chemical Oxygen Demand (BOD, COD). They reported that the presence of metals and other dye compounds inhibit microbial activity and some cases may cause failure of biological treatment system.

EPA (1974) reported that the pollutional parameters in textile wastewater effluents are suspended solids, BOD, COD, nitrogen, phosphate, temperature, toxic chemicals (phenol), chromium and heavy metals, $\mathrm{pH}$, alkalinity-acidity, oils and grease, sulphides, and coliform bacteria. FEPA (1991) also supported these and demands for their proper monitoring in the textile effluents in the country. Textile effluents are high in BOD due to fibre residues and suspended solids (AEPA, 1998). They can contaminate water with oils, grease, and waxes (Akintunde, 1986) while some may contain heavy metals such as chromium, copper, zinc and mercury (EPA 1974). Dyeing process usually contributes chromium, lead, zinc and copper to wastewater (Benavides, 1992). Copper is toxic to aquatic plants at concentrations below $1.0 \mathrm{mg} / \mathrm{l}$ while concentration near this level can be toxic to some fish (Sawyer and McCarty, 1978).

\section{METHODOLOGY}

All field meters and equipment (Table 2) were checked and calibrated according to the manufacturers specifications. The $\mathrm{pH}$ meter was calibrated using HACH (1997) buffers of $\mathrm{pH} 4.0$, 7.0 and 10.0; TDS/conductivity/salinity meter was calibrated using the potassium chloride solution provided by the manufacturer $(\mathrm{HACH}$, 1997); the spectrophotometers (HACH DR890 and DR2010) were checked for malfunctioning by passing standard solutions of all the parameters to be measured; Blank samples (deionized water) were passed between every three measurements of effluent samples so as to check for any eventual contamination or abnormal response of equipment. Reproducibility of results was regularly checked by carrying out periodic analysis of aliquots collected from one sample. 
Table 2. Analytical Equipment and Materials Used in the Study

\begin{tabular}{l|l|l|l|l}
\hline S/No & Equipment & Model & Manufacturer & Age \\
\hline 1 & Spectrophotometer & DR 890 & HACH & $<1$ year \\
2 & Spectrophotometer & DR 2010 & HACH & 3 years \\
3 & COD Digestion Reactor & 45600 & HACH & 3 years \\
4 & Conductivity Meter & CO 150 & HACH & 3 years \\
5 & pH Meter & - & HACH & $<1$ year \\
6 & Dissolved Oxygen Meter & 9071 & Jenway & 3 years \\
7 & Water Sampler & $1520-C 20$ 0298 & WILDCO & 3 years \\
8 & Electronic Balance & WA 210 Rev-B & Adam Equipment & 3 years \\
9 & Digital Titrator & - & HACH & $<1$ year \\
10 & Incubator & OV 160 C & Genlab & 3 years \\
11 & Dessicator & - & - & 3 years \\
12 & Electromantel & 10102315 & Electrothermal & 3 years \\
13 & Water De-ionizer & B 114 & Elgacan & 3 years \\
14 & Water De-ionizer Catridge & C 114 & Elgacan & - \\
15 & Atomic Absorption & ALPHA 4 & ChemTech & 3 years \\
& Spectrophotometer & & Analytical Instr. & \\
\hline
\end{tabular}

The fieldwork involved taking samples at points at which effluents discharge into drains for laboratory analyses. Two litres of each sample was taken in plastic containers and one litre per sample was taken in bottles for oil and grease determination. The samples were taken during the period of heaviest activity corresponding to the highest volume discharge and hence the worst situation. There was a need for sample preservation and for all the parameters, $\mathrm{HACH}$ (1997) recommended methods were used.

In-situ measurements for some of the parameters - $\mathrm{pH}$ and temperature - were carried out using portable HACH conductivity meter. Determination of other parameters (total dissolved solids (TDS), total suspended solids (TSS), colour, nitrate, ammonia, and sulphide) was carried out in the laboratory using the spectrophotometers. Heavy metal (aluminum, chromium, iron, zinc, manganese, and copper) determination was carried out using atomic absorption spectrophotometer (AAS).

For oil and grease concentration determination, gravimetrical method (APHA, 1998) was used after solvent extraction with xylene. Chemical oxygen demand (COD) was determined by the dichromate digestion method while biochemical oxygen demand (BOD) was determined by the dilution method.

\section{RESULTS}

Generally the effluents characteristics need to be properly monitored for better environmental protection. Though all the textile mills had their effluent temperatures between 26 and $35.7{ }^{\circ} \mathrm{C}$ (Table 3) which are below the set limit by the Federal Environment Protection Agency (FEPA, $1991)$, the $\mathrm{pH}$ range $(10-11.5)$ calls for more attention. These effluents were basic in nature. The colours of all the effluents were several times higher than the allowable limit of 7 Pt-Co. They ranged from 612 - 4637 Pt-Co with effluents from mills 1,3 and 4 having values above 2250 Pt-Co. With the exception of wastewater from mill 2 that has a TDS concentration of $2200 \mathrm{mg} / \mathrm{l}$ the other effluents had TDS levels within the acceptable limit of $2000 \mathrm{mg} / \mathrm{l}$. Though the total suspended solids levels in the effluent from mill 2 and mill 5 could be acceptable, the effluents from the other mills had TSS levels of more than eight folds of the acceptable limit. Both measured BOD and COD levels also exceed the set limit by about three and thirteen folds respectively. Apart from mills 2, 4 and 5, the sulphide levels in the effluents were high $(0.58-0.64 \mathrm{mg} / \mathrm{l})$ as against the standard limit of $0.2 \mathrm{mg} / \mathrm{l}$. Ammonia levels were high in all the effluents $(1.82-2.72 \mathrm{mg} / \mathrm{l})$ except in mill 4 that had a lower value of 0.05 $\mathrm{mg} / \mathrm{l}$. Nutrients and micro-nutrients (nitrate, iron, calcium and manganese) were all below the national standard. Oil and grease was detected in the effluents from mills 1 and 2 and both were below the $6.0 \mathrm{mg} / \mathrm{l}$ national limit. With the exception of copper, heavy metals concentrations were below the set limits in all the effluents 
Table 3. Physico-chemical Characteristics of Effluents from the Textile Mills

\begin{tabular}{l|l|l|l|l|l|l}
\hline Parameter & FMENV. Limit & Mill 1 & Mill 2 & Mill 3 & Mill 4 & Mill 5 \\
\hline Flow rate $\left(\mathrm{m}^{3} /\right.$ day) & & 10,900 & 17,800 & 35,000 & 17,280 & 16,200 \\
$\mathrm{pH}$ & $6-9$ & 10.21 & 11.23 & 11.04 & 11.53 & 10.47 \\
Temperature $\left({ }^{\circ} \mathrm{C}\right)$ & 40 & 31.8 & 35.7 & 33.5 & 26.7 & 26.7 \\
Colour $($ Pt-Co) & 7 & 2275 & 612 & 3537 & 4637 & 968 \\
TDS & 2000 & 1130 & 2200 & 1480 & 848 & 250 \\
TSS & 30 & 245 & 35 & 471 & 1200 & 49 \\
Sulphide & 0.2 & 0.64 & 0.11 & 0.58 & 1.94 & 0.1 \\
Free chlorine & 1 & 0.01 & 0.01 & 1.14 & 1.06 & 0.76 \\
COD & 80 & 2120 & 1650 & 2430 & 2190 & 1067 \\
BOD & 50 & 227 & 382 & 645 & 242 & 163 \\
Oil \& Grease & 10 & 6.0 & 8.3 & ND & ND & ND \\
Dissolved Oxygen & - & 2.5 & 2.9 & 3.08 & 1.2 & 7.0 \\
Nitrate & 20 & 7.97 & 0.8 & ND & ND & ND \\
Ammonia & 0.2 & 1.82 & 2.01 & 1.28 & 0.05 & 2.72 \\
Phosphate & 5 & 3.42 & 0.09 & 2.63 & 0.74 & 0.36 \\
Calcium & 200 & 2.21 & 1.8 & 1.24 & 0.26 & 2.4 \\
Magnesium & 200 & 1.21 & 1.76 & 1.04 & 0.17 & 2.1 \\
\hline ND: Not Des
\end{tabular}

ND: Not Detected

Units in mg/l unless otherwise stated.

Table 4. Heavy Metal Concentrations in Kaduna City Textile Mills' Effluents

\begin{tabular}{l|l|l|l|l|l|l}
\hline Parameter & FMENV. Limit & Mill 1 & Mill 2 & Mill 3 & Mill 4 & Mill 5 \\
\hline Chromium & $<0.1$ & ND & ND & ND & ND & 0.5 \\
Aluminum & $<1.0$ & 0.02 & 0.11 & 0.14 & 0.61 & ND \\
Copper & $<1.0$ & 1.96 & 2.04 & 1.16 & 5.14 & ND \\
Manganese & 5.0 & 0.35 & 1.65 & 1.18 & 0.3 & ND \\
Iron & 20.0 & 1.14 & 0.45 & 2.14 & ND & ND \\
Zinc & $<1.0$ & 0.33 & 0.36 & 0.31 & 0.19 & ND \\
Mercury & 0.05 & ND & ND & ND & ND & ND \\
\hline
\end{tabular}

(Table 4). Four of the wastewaters (mills 1, 2, 3 and 4) had copper levels range of between 1.96 and $5.14 \mathrm{mg} / \mathrm{l}$ as against lower set (less than 1.00) limit. While chromium was not detected in four of the textile effluents, mill 5 effluent had a value of $0.5 \mathrm{mg} / \mathrm{l}$ that was still below the standard. Mercury was not detected in all the samples tested.

\section{DISCUSSION OF RESULTS AND AIR QUALITY IMPLICATIONS}

The most important measure of water quality is the dissolved oxygen (Peirce et al., 1997). The low level of DO recorded could result in the nonmaintenance of conditions favourable to the aerobic organisms. This could lead to anaerobic organisms taking over with the resultant creation of conditions making the water body uninhabitable to gill-breathing aquatic organisms. Hydrogen sulphide is formed under conditions of deficient oxygen in the presence of organic materials and sulphate (WHO, 2000). This could be a possible reason for the high sulphide measured in the effluents analyzed. The high levels of BOD are indications of the pollution strength of the wastewaters. They also indicate that there could be low oxygen available for living organisms in the wastewater when utilizing the organic matter present. High COD levels imply toxic condition and the presence of biologically resistant organic substances (Sawyer and McCarty, 1978). The settleable and suspended solids are high and this will affect the operation and sizing of treatment units. Solids concentration is another important characteristic of wastewater (Lee and Lin, 1999). High 


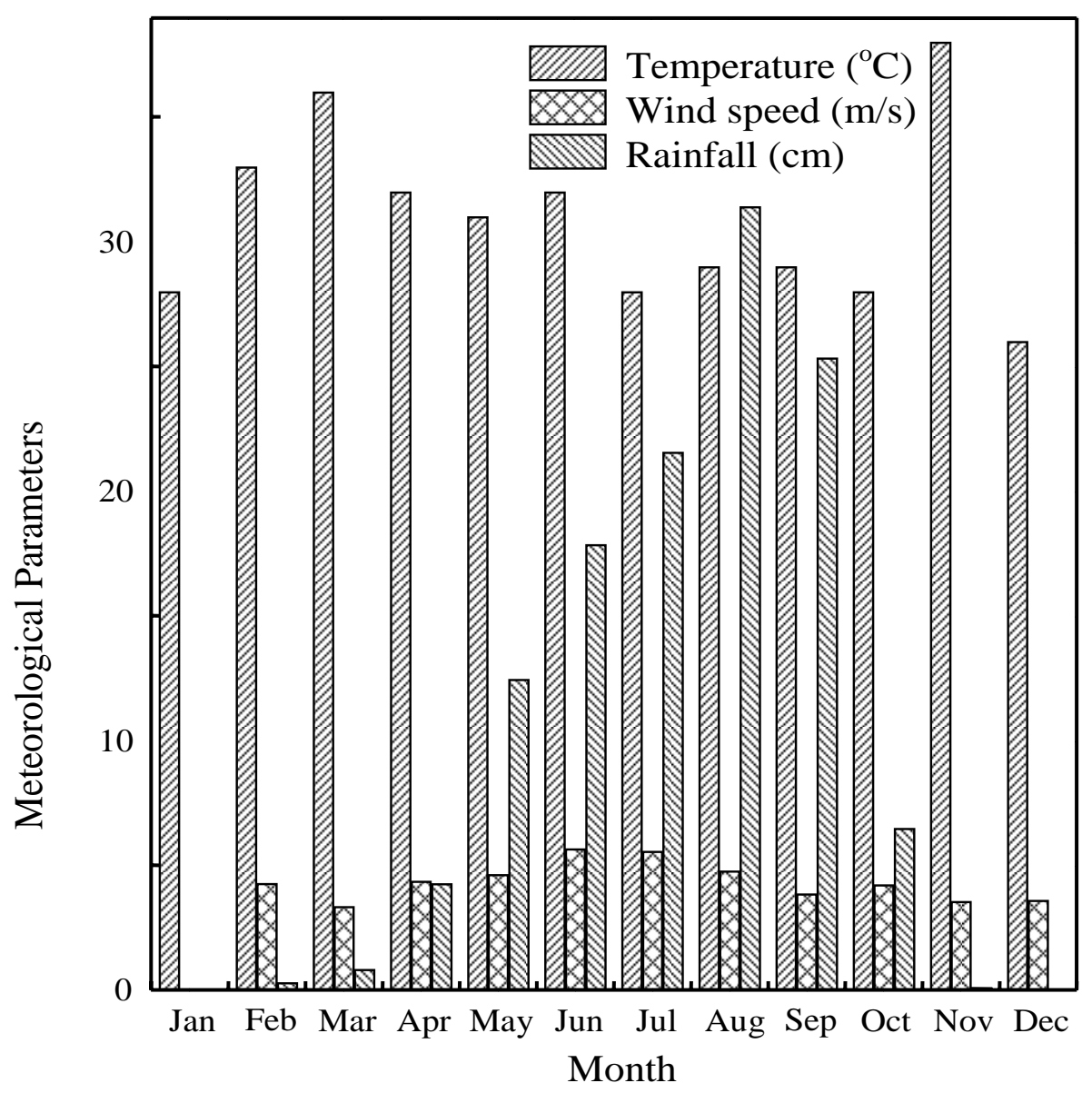

Figure 3. Typical Mean Monthly Temperature, Wind Speeds and Rain Fall in Kaduna Area

alkalinity increases with wastewater strength. It shows the capacity of wastewaters to neutralize acids, and is undesirable.

Heavy metals in the wastewaters could be of negative impact to the environment. Sekhar et al. (2003) traced heavy metal contamination of an area to industrial effluent. The negative impacts from Kaduna textile mills effluents could be felt as far as all the regions covered by the Kaduna River basin (Figure 1), the main receptor of these effluents. Adeniji and Mbague (1990) once detected high heavy metal concentration in Jebba and Kainji Lakes and Ita (1994) attributed this to some industries along the rivers Niger and Kaduna. The textile industries which are some of the most active in the city (Kaduna) could be one of the sources and this confirms the potential dangers associated with high copper levels detected in the effluents analyzed.

In Nigeria, climate is determined primarily by the distance from the ocean to the secondary elevation hills and as such, the temperature is always warm and precipitation decreases from the coast to the Sahel in the North (Lae et al., 2003). While high temperature increases evaporation rate of wastewaters thus polluting the air of an area, washout effect associated with rainfall (Jauregui and Luyando, 1999) which is characterized by high precipitation, reduces air pollution. The two climatic conditions of the Northern Nigeria under which Kaduna city falls is an indication that adequate efforts should be made to prevent air pollution. The natural cleansing of air pollution in the area could be low due to low precipitation and associated high wind speed (Figure 3) while the reverse is the case for its air pollution inducing potential (due to high temperature). Akeredolu and Sonibare (1997) once predicted lower ventilation coefficient (a natural way of air pollution removal) for Kano, a neighboring city to Kaduna.

Air pollution of the detected effluents' parameters could be in gaseous and particulates form and the potential threat they pose to the environment especially around River Kaduna 
basins calls for stringent control measure. Of the five world air pollution episodes, three of them (1930, 1948, and 1952) happened around riverbanks (EPA, 2004) supported by temperature inversions.

Oil and grease, ammonia, sulphides, and colour, are potential air pollution sources from these effluents. Meteorological conditions which include wind speed and annual average temperature (EPA, 2002) are important factors. At any temperature, liquids can evaporate due to higher kinetic energy of some molecules. These molecules with higher kinetic energy will be able to escape the intermolecular attractive forces in the liquids and enter the gas phase. Evaporation increases as the liquid temperature increases due to the increased number of molecules with the necessary kinetic energy level to escape. This confirms that high temperature of Kaduna city (Figure 3) especially during the long dry season (Kaduna, 2004) could increase the potential of the discharged effluents from the textile mills to pollute air in the environment. High colour associated with these effluents should be adequately treated before discharge. The impacts of temperature on diffusivities both in the air and water (EPA 2001) could influence emissions of both ammonia and sulphides detected in the effluents while volatilization of oil and grease that could be induced by the same high temperature could introduce organic compounds into the environment thus polluting the air.

When the effluents are discharged into the river, heavy metals present can be adsorbed on the river's soil and sediments and during the dry season, water evaporation could expose them to the environment. High TSS and TDS detected could be attributed to the high colour (from the various dyestuffs being used in the textile mills) and they may be major sources of the heavy metals. Increased heavy metals concentrations in river sediments could increase suspended solids concentrations (Kambole, 2003). During the dry season, the occasional dust re-suspension could introduce these metals into the atmosphere along with the particulates. With this, they could constitute health problems in form of air pollution. Some of the vapours formed above have great potential to nucleate thus becoming particulate problem to the environment. In addition to these are the products of reactions between some of the chemicals present in the effluents (Soldan, 2003) which may be toxic to the environment. Removal of the pollutants from these effluents is the only sure way of safer environment and this can be achieved by treatment to required level.

\section{CONCLUSIONS}

The qualities of effluents studied were grossly below the set limits by the Federal Ministry of Environment in Nigeria and some world bodies like the World Health Organization in four of the five textile mills. The effluents are not uniform in characteristics and this may make it extremely difficult to use a central effluent treatment plant as being proposed by the government. Lower levels of some of these parameters in Mill 5 (with effluent treatment plant) when compared to the other four mills (with no effluent treatment plant) indicate that a uniform characteristics is attainable for or all the effluents if a measure of treatment is introduced at Mill level. Lower levels of parameters could make the proposed central treatment plant cheaper to maintain even at greater efficiency.

The results also show that air quality of the area covered by the entire Kaduna river basin could be negatively affected by both the gaseous emissions and particulates which could be released from the effluents. Meteorological conditions of the area are strong influencing factors. Rainfall appears in Kaduna around May and retreats in September (Odekunle, 2004). The associated relatively high wind speed and low temperature (Figure 3) during this period could lower air pollution problems but the situation may not be the same for the longer dry season.

Incorporation of appropriate heavy metal recovery in the proposed central effluent treatment as proposed by Gaballah and Kilbertus (1998) could be of great advantage for environmental protection especially around the river banks where animals do concentrate during the dry season in the Northern part of Nigeria (Alawa et al., 2002), a region where Kaduna city belongs. The impacts around these banks could be much (since it is the final receiving point of the effluents) if adequate measures are not taken before the final discharge.

\section{REFERENCES}

Adeniji H.A. and Mbagwu I.G. (1990), Study of Physico-chemical Characteristics of Some Heavy Metals in Jankara Reservoir, Kano State, Nigeria, In: NIFFR Annual Report, pp. 136 - 140. 
AEPA (Australian Environmental Protection Authority) (1998), Environmental Guidelines for the Textile dyeing and Finishing Industry, State Government of Victoria, Melbourne, Victoria, Australia.

Akeredolu F.A. and Sonibare J.A. (2002), Ventilation Coefficient of Two Industrial Cities of Nigeria and Air Pollution Control Implications, Journal of the Nigerian Meteorological Society (NMS), 3, 4259.

Alawa J.P., Jokthan G.E. and Akut K. (2002), Ethnoveterinary Medical Practice for Ruminants in the Subhumid Zone of Northern Nigeria, Preventive Veterinary Medicine, 54, 79-90.

APHA (American Public Heath Association) (1998), Standard Methods for the Examination of Water and Wastewater, WEF and AWWA, 20th Edition, USA.

Benavides L. (1992), Expert Group meeting on Local Cottage Industries of Hazardous Wastes from Small-scale and Cottage Industries, An Overview.

EPA (1974), Wastewater-Treatment Systems: Upgrading Textile Operations to Reduce Pollution, United States Environmental Protection Agency, Washington DC, USA, In: EPA Technology Transfer, EPA-625/3-74-004, pp $1-12$.

EPA (2001), Integrated Risk Information System (IRIS). National Center for Environmental Assessment, Office of Research and Development, Washington DC, USA, available on line at http:/www.epa.gov/iris/.

EPA (2002), Industrial Waste Air Model Technical Background Document, United States Environmental Protection Agency, USA, EPA 530-R-02-010.

EPA (2004), Introduction to Air Pollution Control, http://www.epa.gov/air/oaqps/eog/control. Accessed on May 21, 2004.

FEPA (Federal Environmental Protection Agency) (1991), Guidelines to Standards for Environmental Pollution Control in Nigeria, Lagos, Nigeria.

Gaballah I. and Kilbertus G. (1998), Recovery of Heavy Metal Ions through Decontamination of Synthetic Solutions and Industrial Effluents using Modified Barks, Recovery of Geochemical Explorations, 62, 241-286.

Gefu J.O. and Kolawole A. (2002), Conflict in Common Property Resource Use: Experiences from an Irrigation Project, In: 9th Biennial Conference of the International Association for the Study of Common Property (IASCP), Victoria Falls, Zimbabwe, June 2002.

Ghoreishi S.M. and Haghighi R. (2003), Chemical Catalytic Reaction and Biological Oxidation for Treatment of non-Biodegradable Textile Effluent, Chemical Engineering Journal, 95, 163169.

HACH (1997), Water Analysis Handbook, 3rd edition, HACH Company, Loveland, Colorado, USA.

Ita E.O. (1994), Aquatic plants and wetland wildlife resources of Nigeria, CIFA Occasional Paper, No. 21, Rome, FAO, pp 52.

Jauregui E. and Luyando E. (1999), Global Radiation Attenuation by Air Pollution and its Effects on the Thermal Climate of Mexico, International Journal of Climatology, 19, 683-694.

Jibrin W. (2004), Dilemma of Textile Industries in Nigeria, In: 1st Economic Summit, Arewa House Kaduna, April 2004.

Kaduna (2004), The Official Website of Kaduna State, Nigeria, www.kaduna-state.com, accessed on May 20th 2004.

Kambole M.S (2003), Managing the Water Quality of the Kafue River, In: Physics and Chemistry of the Earth, Parts A/B/C, 28 (20-27), pp 1105-1109.

Kupechella C.E. and Hyland M.C. (1989), Environmental Science, Allyn and Baron, London.

Lae R., Williams S., Mallam M.A., Morand P. and Mikolasek O. (2003), Review of the Present State of Knowledge of Environment, Fish Stocks, and Fisheries of the River Niger (West Africa), In: Second International Symposium on the Management of Large Rivers for Fisheries: Sustaining Livelihoods and Biodiversity in the New Millennium, Phnom Penh, Kingdom of Cambodia, 11th-14th Feb. 2003, pp 45.

Lee C.C. and Lin S.D. (1999), Handbook of Environmental Engineering Calculations, McGraw Hill, New York.

Nemerow, N.L. (1978) Industrial Water Pollution: Origins, Characteristics and Treatment. AddisonWesley, Reading, Massachusetts, pp 738. 
Novick R. (1999), Overview and the Health in Europe in the 1990s, World Health Organization, Europe Regional Office, Copenhagen, EUR/ICP/EH/CO 02 02 05/6, pp 20.

Odekunle T.O. (2004), Rainfall and the Length of Growing Season in Nigeria, International Journal of Climatology, 24, 467-479.

Olanrewaju D.O (2001), Urban Infrastructure: A Critique of Urban Renewal Process in Ijora Badia, Lagos, Habitat International, 25, 373-384.

Peirce J.J., Weiner R.F. and Vesilind P.A. (1997), Environmental Pollution and Control, ButterworthHeinemann, Woburn, MA, 4th Edition USA, pp 57-74.

Pollution Research Group (PRG) (1998), Waste Minimization Guide for the Textile Industry - A Step Towards Cleaner Production, University of Natal, Draft Volumes 1 and 2.

Sawyer C.C. and McCarty P.L. (1978), Chemistry for Environmental Engineers, McGraw Hill, New York. pp 331-514.

Sekhar K.C., Chary N.S., Kamala C.T., Rao J.V., Balaram V. and Anjaneyuly Y. (2003), Risk Assessment and Pathway Study of Arsenic in Industrially Contaminated Sites of Hyderabad: A Case Study, Environmental International, 29, 601-611.

Soldan P. (2003), Toxic Risk of Surface Pollution - Six Years of Experience, Environment International, 28, 677-682.

Tamburlini G., Ehrenstein O.V. and Bertollini R. (2002), Children's Health and Environment: A Review of Evidence, In: Environmental Issue Report No. 129, WHO/European Environment Agency, WHO Geneva, pp 223.

TWG (2004), Current Population Figures for Cities, Towns, and Administrative Divisions of the World, http://www.world-gazetteer.com/home.htm, Accessed on May 21, 2004

Villegas-Navarro A., Ramirez M.Y., Salvador-S M.S. and Gallardo J.M. (2001), Determination of Wastewater LC $_{50}$ of the Different Process Stages of the Textile Industry, Ecotoxicology and Environmental Safety, 48 , 56-61.

WHO (1993), Guidelines for Technologies for Water Supply Systems in Small Communities, World Health Organization, CEHA 1993

WHO (2000), WHO Air Quality Guidelines, 2nd Edition, World Health Organization, Europe Regional Office, Copenhagen.

WHO (2002), Water Pollutants: Biological Agents, Dissolved Chemicals, Non-dissolved Chemicals, Sediments, Heat, WHO CEHA, Amman, Jordan.

WHO (2003), The World Health Report 2003: Shaping the Future, World Health Organization, 1211 Geneva 27, Switzerland.

Wynne G., Maharaj D. and Buckley C. (2001), Cleaner Production in the Textile Industry - Lessons from the Danish Experience, School of Chemical Engineering, University of Natal, Durban, South Africa, pp3. 